\title{
An Analogical Hermeneutic Approach to Bioethics
}

\author{
David S. Contreras Islas \\ Division of Social Sciences and Humanities, Autonomous Metropolitan University, Mexico City, Mexico \\ Email: davidcontc@yahoo.com
}

How to cite this paper: Contreras Islas, D. S. (2018). An Analogical Hermeneutic Approach to Bioethics. Open Journal of Philosophy, 8, 28-44.

https://doi.org/10.4236/ojpp.2018.81004

Received: January 10, 2018

Accepted: February 24, 2018

Published: February 27, 2018

Copyright $\odot 2018$ by author and Scientific Research Publishing Inc. This work is licensed under the Creative Commons Attribution International License (CC BY 4.0).

http://creativecommons.org/licenses/by/4.0/

\section{(c) (i) Open Access}

\begin{abstract}
Bioethics has the hermeneutical task of interpreting scientific knowledge produced by the biological and social sciences in order to propose moral norms and values that are adequate to it. Therefore, it needs to account for the process of translating descriptive statements into normative ones, without falling prey to the naturalistic fallacy. It also requires an interdisciplinary conception of human nature as the basis for the hermeneutical process. That conception should avoid a univocal anthropocentrism as well as an equivocal biocentrism and reconcile the biological and historical dimensions that constitute the human being. This paper examines analogical hermeneutics, as proposed and developed by the Mexican philosopher Mauricio Beuchot, as a largely unplumbed resource for meaningfully illumining inescapable challenges and tensions at the core of bioethics. In brief, the author suggests that analogical hermeneutics can provide bioethics with a philosophical framework for the normative interpretation of descriptive statements. An analogical-hermeneutical approach is suggested for other bioethical problems, such as the elaboration of an interdisciplinary notion of human nature or the search for alternatives to anthropocentric and biocentric positions.
\end{abstract}

\section{Keywords}

Analogical Hermeneutics, Bioethics, Analogical Ethics, Human Nature, Anthropocentrism

\section{Introduction}

It is already 90 years since the German theologian Fritz Jahr coined the term "Bio-Ethik" in a paper published by Kosmos in 1927. Throughout those years, bioethics has developed as an interdisciplinary field of production and application of knowledge, as a merging point for social and biological sciences to deal 
with the normative dilemmas that arise from the interaction of human beings with life in general.

One of the central tasks of bioethics consists in interpreting scientific knowledge produced by social and biological sciences (about nature in general, and human nature in particular) to obtain normative statements, i.e. moral norms and values, in order to provide orientation for scientific (but also political) decision-making. The idea behind this process was already presented in Jahr's paper, but is better expressed by the American biochemist Van R. Potter in 1971, when he writes that in order to face the future challenges of our species "ethical values cannot be separated from biological facts" (Potter, 1971a: vii, emphasis in the original).

As a consequence of that central task, bioethics has to solve the philosophical problem of validating the translation of descriptive statements into normative ones without incurring what Hume, Moore, and other philosophers called the naturalistic fallacy. However, there are other hermeneutical tasks that bioethics needs to fulfill. For example, it needs to build an interdisciplinary notion of human nature out of the interpretation of knowledge generated by biological and social sciences; therefore, it needs to find a balance between the discourses of these sciences to avoid reductionisms of any kind. In addition to this, the bioethical notion of human nature must find a mediating position between anthropocentrism and biocentrism to situate itself.

Anthropocentric positions consider humanity as "the central element on earth" (Potter, 1996: p. 178), thus being superior to (and more valuable than) any other living creature or system. Biocentric positions, on the contrary, consider all living forms to be equally important, usually denying any special attribute to human existence. Both positions are to be avoided: the first one, because of the violence and exploitation of nature it allows; the second one, because of the indifference towards human extinction it might lead to. An analogical position would be closer to the American bioethicist Van R. Potter when he states that "we have to realize that (...) the biosphere (...) is the central element in our existence but (...) that the human species bears the central responsibility for its own survival through preservation and restoration of the biosphere on this planet" (Potter, 1996: p. 179).

This paper discusses a possible application of analogical hermeneutics, developed by the Mexican philosopher Mauricio Beuchot, as a response to these and other problems and challenges that bioethics faces. It begins with an exposition of some general characteristics of Beuchot's analogical hermeneutics, as well as his proposal of an analogical ethics, in order to provide a theoretical framework for further discussion. The section following picks up four moments of bioethics' historical development to show how analogical hermeneutics might be applied to the main problems arising in each one of them. Section 4 deals with the hermeneutical task of elaborating a notion of human nature that is suitable for bioethics, as well as with the process of interpreting this notion to obtain normative 
statements. It discusses how analogical hermeneutics might be applied in order to orientate this process. The last section summarizes the conclusions reached in the previous discussion and highlights the potential benefits facilitated by an analogical-hermeneutical approach to bioethics.

The paper generally concludes that analogical hermeneutics can be upheld as a normative interpretation of descriptive statements, since such an interpretation is one of bioethics' central problems. Moreover, an analogical-hermeneutical approach might also be useful to mediate between the characteristic tensions that bioethics presents, such as balancing anthropocentrism and biocentrism.

\section{Analogical Hermeneutics and Analogical Ethics}

Analogical hermeneutics is the name of a theoretical and methodological framework developed by the Mexican philosopher Mauricio Beuchot. As indicated by its name, analogical hermeneutics is built upon the concept of analogy, meaning "proportion", which the Pythagoreans first introduced to the field of philosophy and which Aristotle developed further. Beuchot's hermeneutics likewise integrates key features from medieval thinkers like Augustine of Hippo and Thomas Aquinas and from American pragmatists like Charles Sanders Pierce (Beuchot, 2015; Conde Gaxiola, 2001).

Originally conceived as a discipline for the interpretation of sacred texts, hermeneutics faces the problem of mediating between univocal (i.e. textual or literal) and equivocal (i.e. allegorical or relativistic) approaches to its object. For Beuchot, the conflict between these two positions is a constant in the history of hermeneutics, which could be roughly described as the struggle between (univocal) literalists and (equivocal) allegorists. Analogical hermeneutics is presented as an alternative to surpass the problematic consequences of univocal and equivocal interpretations (Beuchot, 2015).

In the middle ages, for example, allegorist monks searched for the mystical and spiritual meaning of the Holy Scripture. By contrast, scholastic philosophers seemed more interested in its historical and literal meaning. In the middle of the two positions, some exceptional analogists could be found, like Bonaventure or Thomas Aquinas (Beuchot, 2015). Allegorists and literalists can likewise be found in the Enlightenment, particularly among romanticists and positivists. Even the conflict of modernism and postmodernism can be studied in terms of the latter's equivocal response to the former's univocal project (Beuchot, 2003; Beuchot, 2008a).

While the univocal position allows only one valid interpretation of the text, the equivocal position affirms the validity of each and every interpretation. Accordingly, the former leaves no margin for hermeneutical flexibility, while the latter results in the trivialization of hermeneutics. Therefore, both extremes must be avoided. In the interest of obtaining this goal, Beuchot urges hermeneuts to recognize the importance of contextualizing the text: “...interpreting is putting a text in its context. In the hermeneutic event or the interpretive act, a text inter- 
venes [...]. But that text has an author. And, likewise, a reader or interpreter, who is the interpreter." (Beuchot, 2015: p. 14). Contextualization thus establishes evaluative parameters wherein to assess the validity of different interpretations.

Because of its mediating position between the univocal and the equivocal extremes, and the expertise required by the interpreter to achieve it, the hermeneutical action can be considered as a virtue in the Aristotelian sense. Beuchot refers to it as the "hermeneutical virtue", and places it into the category of the epistemic virtues. Hermeneutical virtue could be described as: "the qualified interpretation, formed by experience and study, but mainly by the interpretative praxis on many texts." (Beuchot, 2006: p. 240).

However, there is more than the Aristotelian concept of virtue to trace a relation between ethics and hermeneutics. Beuchot sustains the existence of a hermeneutical component in every ethical theory: interpreting human nature, society and culture as a text is a necessary first step in order to conceive moral norms and values that are adequate to them (Beuchot, 2004a). He argues against the naturalistic fallacy presented by Hume, Moore and others, and defends that the transition from descriptive to prescriptive sentences is not only possible but necessary, and might be oriented by hermeneutical virtue (Beuchot, 2008b; Beuchot, 2013).

Thus, hermeneutical virtue has a central importance for ethics. An interpretation of human nature that tends to the equivocal or allegorical position will lead to a lack of parameters morally to evaluate any action. That is the problem that Beuchot observes in most postmodern positions, which reject any trace of essentialism to focus on pure existence. Certainly, the relationality and temporality implied by the ontological category of existence are part of human nature, but "an excessive emphasis on existence can lead to relativism and historicism, to particularism and contingentism, which are new expressions of nominalism" (Beuchot, 2008c: p. 132).

On the other side, an interpretation of human nature that tends to the univocal or literal position leads to imperatives that are too rigid to be followed. For Beuchot, that was the problem of most rationalistic ethics, which were conceived from a perspective of pure essence at the expense of the ontological category of existence. While focusing on the category of existence leads to new forms of nominalism, an attempt to base ethics in a decontextualized pure essence leads to new forms of Platonism (Beuchot, 2008c).

A virtuous interpretation of human nature avoids pure essentialism as well as pure existentialism. It recognizes the historical and contextual attributes of human existence, but does not deny the possibility of finding some essential characteristics of human nature. In doing so, for example, it can lead to the recognition of the existence of basic human needs (most of them with a biological basis), whose satisfaction is achieved by means that change depending on the socio-historical context.

Analogical ethics, which results from the virtuous interpretation of an analogic concept of human nature, "will not be an ethics of law, like the univocal, nor 
of situations or casuistic, like the equivocal, but of virtues, because they have a part that looks at general law and another that cares for the concrete situation" (Beuchot, 2004a: p. 77).

Yet, the applications of analogical hermeneutics to ethics go beyond mediating the conflict between principlism and casuistry. It also presents an alternative to conciliate common good and individual good, which are predicated on the basis of communitarian and libertarian ethics. For Beuchot, this conflict needs to be addressed by recognizing that common good is always also the good of every individual, even if prejudice prevents us from seeing it that way. However, common good must also be sought without harming human rights, which are individual. Furthermore, these rights should be enhanced to gain a communitarian dimension, where every individual (as well as every social institution) cares for the human rights of others (Beuchot, 2004b).

Analogical ethics provides an alternative to surpass the postmodern tension between moral relativism and the new forms of fundamentalism. Applied to political movements like feminism or eco-socialism, it could prevent them to fall into any of the two extremes mentioned above. Additionally, this approach can also be helpful for understanding phenomena like bioethics, which involve a constant process of interdisciplinary reinterpretation of human nature in order to make new ethical statements.

\section{Analogic Ethics and Bioethics}

This section presents a brief exposition of the history of bioethics. Its aim is to highlight some aspects of bioethics that are similar to analogical ethics, or that could profit from an analogical-hermeneutical approach. We will focus on four main moments of the historical development of bioethics: 1) the original project of Fritz Jahr, with an emphasis on his bioethical imperative; 2) the perspective of bioethics as a science of survival, developed by Van R. Potter; 3) the development of principlism as a framework for medical bioethics by Tom L. Beauchamp and James F. Childress; and 4) the recent concern to retrieve the biocentric dimension of bioethics.

\subsection{Fritz Jahr and the Bioethical Imperative}

The word "bioethics" was coined by the German theologian Fritz Jahr in 1927, when the Journal Kosmos published his paper "Bio-Ethik. Eine Umschau über die ethischen Beziehungen des Menschen zu Tier und Pflanze" (Bio-ethics. An overview of the ethical relationships of humans to animals and plants). Because of that publication, some authors consider Jahr the father of bioethics (Sass, 2011; Steger, 2015; Rawlinson, 2015).

Jahr proposed a universal bioethical imperative as an alternative to Kant's categorical imperative, which called to "regard every living being in principle as an end in itself and treat it accordingly as far as possible." (Jahr, 1927: p. 4). According to Steger (2015), the main interest of Jahr was to reevaluate human be- 
havior in the context of scientific and technical developments of his time, which allowed questioning the prevailing anthropocentrism inherited from modernity. Contrary to it, Jahr defended a physiocentric or biocentric point of view, which is condensed in his reformulation of the categorical imperative.

Jahr's bioethical imperative possesses peculiar characteristics reminiscent of the analogical ethics defended by Beuchot. We must note, for instance, that Jahr's formulation is less inflexible than Kant's (Sass, 2011). Hepromotes the consideration of every living being as an end in itself and to treat it accordingly, but adds that this should be done as far as possible. In doing so, he wants to prevent an equivocal position of excessive biocentrism, which contravenes even human self-preservation.

In doing so, Jahr's imperative comes to be very similar to the analogical-categorical imperative defended by Beuchot:

...the analogical-categorical imperative starts from the Aristotelian principle of synderesis: "Do good and avoid evil", realizing that it is too formal, and that it must be filled up with material contents, which are largely given by the natural inclinations of the human being, mainly those of self-preservation, of the conservation of the species, and of care for the offspring (Beuchot, 2004c: p. 110).

In order to regard every living being as an end in itself and treat it accordingly as far as possible, Jahr seems to agree that it is necessary to consider the natural inclinations of human beings to self-preservation-therefore his critique of "Buddhist fanatics, who do not kill even poisonous vipers with the argument that they 'are also our brothers and sisters"' (Sass, 2011: p. 23). In order to determine how far exactly is "as far as possible", the bioethical imperative has to be interpreted in a particular context.

Jahr's imperative represents a proportional position between biocentrism and anthropocentrism, a flexible position, of course that can change its relationship between both ends depending on the situation. (For instance, in a global situation that urges the conservation of ecological integrity for the survival of the human species, some decisions would probably be closer to the biocentric end of the "Buddhist fanatics").

Jahr recognized the need of bioethics to mediate between both extremes. As a result, he conceived a flexible and contextualized bioethical imperative. Analogy is, thus, present from very beginnings of bioethics, and can be traced to its core. But there are other aspects of bioethics that could profit from an analogical-hermeneutical approach. Some examples are presented following.

\subsection{Van Potter and the Science of Survival}

Bioethics gained popularity in the decade of 1970 due to the work of the American biochemist Van R. Potter. Like Jahr, Potter conceives bioethics as a new discipline, which would bring humanities and social and biological sciences back together in order to "generate wisdom, the knowledge of how to use knowledge for social good from a realistic knowledge of man's biological nature and of the 
biological world." (Potter, 1971b: p. 26). Again, we find the concern to move from the descriptive to the normative sphere: to build an ethical theory consistent with a reinterpretation of human nature that is based on scientific facts.

However, there are some differences between Potter and Jahr. Because of the particularities of his socio-historical context, Potter is concerned about the global scenarios of pollution, overpopulation, ecological degradation, and disease. $\mathrm{He}$ had read Rachael Carson's Silent Spring (Carson, 1962) and was deeply moved by the first report of The Club of Rome in 1972. Therefore, Potter conceives bioethics as a "science of survival", as a "bridge to the future", that should provide orientation to upcoming global policies. In consequence, he gives it the name of "global bioethics" (Potter, 1971b; Potter, 1977; Ten Have, 2012).

The metaphor of the "bridge", which is recurrent in Potter's first works, has a double meaning. On the one hand, it is related to his concern about the survival of the human species; therefore, global bioethics is a "bridge to the future" of humankind (Potter, 1971b). On the other hand, Potter's bioethics aim to be a bridge that connects the traditionally separated fields of biological sciences, social sciences, and the humanities. This conception of bioethics as an interdisciplinary science (Ten Have, 2012) is not explicit in Jahr's work, and represents new challenges that can be approached from the perspective of analogical hermeneutics.

As an interdisciplinary science, bioethics needs to find its own discourse, different from the ones of the disciplines it brings together, but similar enough to allow a continuous dialogue with them. ${ }^{1}$ This task, of course, requires locating possible points of convergence between the disciplines without losing the diversity and richness of each one. It needs to reinterpret the disciplinary discourses: it is a hermeneutical task.

In order to achieve interdisciplinarity, bioethics must ensure that none of the disciplines ends up overshadowing the others. Every form of reductionism must be avoided. Balance must be found, a proportionality between the different disciplinary discourses. Therefore, the construction of a bioethical discourse could be aided by analogical hermeneutics.

Another challenge for bioethics as an interdisciplinary science is the elaboration of a concept of human nature that proportionally integrates the different disciplinary perspectives. This challenge is particularly important, since the normative dimension of bioethics is directly dependent on it, as discussed in the previous section. Potter and Jahr coincide that this concept must take the knowledge produced by biological sciences in consideration; however, the biological aspects should not overshadow other (historical, cultural, or spiritual) dimensions of human nature. Because of its importance, this point will be further discussed in a separate section.

Finally, a comment on anthropocentrism is warranted. It seems clear that, because of its concern for the survival of the human species, global bioethics is

${ }^{1}$ Some of this disciplines are: biology, ecology, evolution, medicine, psychology, history, sociology, political science, law, ethics and philosophy. 
closer to anthropocentrism than bioethics as Jahr conceived it. However, Potter claims that the position adopted by global bioethics should be "not biocentrism, not anthropocentrism, but a combination of both" (Potter, 1996: p. 181). Inspired by the work of the philosopher Max Otto, he names this position "an enlightened nature-conscious anthropocentrism", which would be driven by the search for a "common good" (Potter, 1996: p. 181), in a sense that is close to the analogical interpretation of the common good defended by Beuchot (2004b). Again, this sense leads us to consider bioethics as being deeply related to analogical ethics.

We can conclude that Potter's bioethics maintains, in essence, the search for a mediating position between anthropocentrism and biocentrism. That is, it is an analogical position that, perhaps because of the context in which it was conceived (and because of the conceptualization of bioethics as a science of survival), is closer to the anthropocentric side than Jahr's imperative was.

\subsection{Principlism and Medical Bioethics}

The original projects of Jahr and Potter invited a reconsideration of the ethical dimension of the relations of humans with all other living beings. Despite this invitation, in the following decades bioethics constrained itself to the dilemmas that emerged in the field of medicine as a result of the rapid development of biotechnology during the second half of the $20^{\text {th }}$ century (Callahan, 2015). Most of the philosophical attempts to fundament the new discipline were conceived from this medical perspective, represented by figures like André Hellegers, Daniel Callahan, Tom Beauchamp, and James Childress, among others.

Concern for the survival of the human species or the moral obligation toward other living beings was relegated to the background. Instead, bioethics focused on the problems of clinical research on humans, patient rights, and the dilemmas related to the beginning and end of life (i.e. birth-control, abortion, artificial lengthening of life, or euthanasia). Despite being "more narrow and instrumentalist than the conceptual project envisioned by Jahr and Potter" (Rawlinson, 2015: p. 31), medical bioethics was rapidly adopted by The National Commission for the Protection of Human Subjects of Biomedical and Behavioral Research in the United States, followed by other institutions around the world.

Medical bioethics has the task to provide responses to the ethical dilemmas of daily medical practice. To support the fulfillment of this task, Beauchamp and Childress proposed a theoretical framework based on four prima-facie moral principles that ought to orient medical decision making: beneficence, non-malfeasance, respect for autonomy, and justice (Beauchamp \& Childress, 1979). Published under the name of Principles of Biomedical Ethics, the framework of Beauchamp and Childress continues to be one of the most popular theories in the field.

There are many ways to apply analogical hermeneutics to bioethical principlism. For example, the authors grant that, in order to provide adequate orienta- 
tion, the four principles should be enriched by the context of every specific situation. Thus, medical professionals would constantly need to interpret the given context in order to define what constitutes beneficence or a patient's autonomous will. In doing so, an analogical position has to be achieved between the (univocal) judgment of the authorized medical expert (the doctor) and the particular (equivocal) circumstances of each patient.

Beauchamp and Childress also grant that the four principles may conflict with one another. For example, the autonomy of the patient could go against the principle of justice, just as, in a similar situation, the pursuit of the individual good might compromise the common good. As already discussed, an analogical approach to the problem would show that the common good is always also the good of every individual, but also that it must be achieved by respecting (individual) human rights. Again, the situation urges finding a proportional position. Therefore, we can conclude that, even in the constrained context of medical ethics, bioethics could still profit from an analogical-hermeneutical perspective.

\subsection{Beyond Medial Bioethics: The Call to Retrieve Biocentrism}

The medical orientation, which became the dominant practice of bioethics during the last decades, is much closer to the anthropocentric side than the projects of Jahr and Potter were. Despite the search for an analogical position between individual and common good (usually represented by the principles of autonomy and justice), it does not seem to consider the non-human living beings that make up the community of life. Because of this, dominant medical bioethics are being questioned.

In recent years, some scholars have reacted to the dominant practice by claiming that, in order to fulfill its function as a "bridge to the future", bioethics needs to retrieve its biocentric side. In a similar spirit as Potter and Jahr, the Mexican philosopher Lizbeth Sagolsconsiders, for instance, that the future of bioethics "must take it closer to attaining equality for all beings and it must emphasize ecological issues and the limits thus incurred for human behavior" (Sagols, 2015: p. 25). She calls for humankind to "look after the survival of the forms of life and of the health of the Earth" (Sagols, 2015: p. 25).

In the same line, the American philosopher Mary C. Rawlinson criticizes the dominant medial practice for seeming "content to accept current economic, social or environmental arrangements and practices and to operate instrumentally within them" (Rawlinson, 2015: p. 32). In her paper, she calls for a new bioethics concerned with gender equality, global food issues, and the relation between health and environmental integrity.

Other authors like Alberto Acosta (2011) go a step further to defend the pertinence of creating a frame of Nature Rights, with a similar status as human rights, so as to promote respect and protection for the whole community of life. In a similar way, the Spanish philosopher José M. Gómez-Heras argues for the inclusion of all living beings under the category of moral patients, as a natural 
consequence of the normative interpretation of knowledge produced by biological sciences during the last century (Gómez-Heras, 2012).

This return to biocentrism needs an analogical approach in order to dialogue with the dominant position of medical bioethics. Firstly, to avoid the equivocal and the univocal ends discussed above. Secondly, to be able to dialogue with the philosophical and methodological foundation that medical bioethics developed during its almost 3 decades of hegemony.

It seems reasonable that the Rights of Nature, for example, could be enriched both by Jahr's bioethical imperative, and profit from the framework proposed by Beauchamp and Childress. Redefining the four principles of medical ethics in order for them to be applicable to other living beings considered as moral patients could be an interesting exercise. Such processes of dialogue and reinterpretation could profit from an analogical-hermeneutical approach.

In summary, we can maintain that, throughout its short history, bioethics has been imbued with perspectives, problems, and tensions that can relate to the characteristics of analogical ethics as described by Beuchot. The constant need to mediate between anthropocentric and biocentric positions could be helped by an analogical-hermeneutical approach. The task of extracting normative statements out of descriptive ones could even find a philosophical basis in Beuchot's theory.

Perhaps the most significant converging point of analogical ethics and bioethics is the use of a concept of human nature as the basis for further normative statements. This point will be discussed further in the next section.

\section{The Bioethical Reinterpretation of Human Nature}

Analogical ethics and bioethics converge in the recognition of an ontological basis for elaborating normative statements. That ontological basis is the notion of human nature. As Beuchot writes: "when constructing an ethical theory, we have to look at the natural condition of man, his human condition or human nature, in order to find the morality that may be convenient, adequate, proportional." (Beuchot, 2004a: p. 77).

This section discusses some general aspects that a bioethical notion of human nature should seek. It is divided in two parts. The first considers the construction of an analogical interpretation of human nature beyond anthropocentrism and biocentrism, whereas the second focuses on the proportional position between essentialist and existentialist interpretations that a bioethical notion of human nature should pursue. Both parts consider the problem of an interdisciplinary interpretation of human nature, which is essential for bioethics.

\subsection{Balancing Biocentrism and Anthropocentrism in the Notion of Human Nature}

Jahr's and Potter's bioethical concerns derived from their realization that their contemporary scientific knowledge no longer sustained an anthropocentric notion of human nature. In consequence, they reinterpreted on the basis of scien- 
tific statements and translated it into moral considerations. As a result, bioethics was born.

This hermeneutical process of translating descriptive (scientific) statements into normative ones lies at the core of bioethics, as expressed by Potter: "What we must now face up to is the fact that human ethics cannot be separated from a realistic understanding of ecology in the broadest sense. Ethical values cannot be separated from biological facts." (Potter, 1971a: vii, emphasis in the original).

However, if bioethics ought to be an interdisciplinary science, as Potter envisioned it, its notion of human nature should not fall into a biological reductionism that overshadows other disciplinary approaches. Rather, the interdisciplinary dimension of bioethics should be already present in its very notion of human nature. Thus, an analogical reinterpretation of human nature could be useful in order to balance "both its natural side and its cultural side, its biological side and its psycho-social side" (Beuchot, 2013: p. 110).

In addition, a bioethical notion of human nature should also search for a proportionality between anthropocentrism and biocentrism. It should clarify that humans belong to the vast community of organisms on Earth, while emphasizing its obligation to respect and protect non-human life. This cannot be achieved form a pure anthropocentric position, which considers humankind as essentially different from (and hierarchically superior to) all other living forms. The image of humans as rulers of nature spread by modern European colonialism, which justified domination, exploitation and violence towards all "inferior" living forms (many humans included), was ultimately based in this kind of (univocal) anthropocentrism. On the other hand, however, pure a biocentrism where all living beings are considered exactly equal in importance, might lead to equivocal positions that cannot sustain any special value of human live, but also any special responsibility to protect non-human life. To avoid equivocal biocentrism, which can be found in numerous radical eco-ethics, Sagols argues that all ethical theory needs to maintain an anthropocentric minimum (Sagols, 2013).

An analogical notion of human nature would probably be similar to the "enlightened nature-conscious anthropocentrism" defended by Potter (1996). That is, on the one hand, a position that accepts the biological, ecological, and evolutionary dimensions of human nature, which are fundamental to understand the existence and survival of the species. Humans are, from that perspective, no different from every other living organism. On the other hand, however, enlightened anthropocentrism recognizes the unique cultural and technological capacities that humans have to transform nature and of affecting the evolution of all species-including its own. The fact that we can actually realize that unique capacity makes us responsible for the future of our own species, as well as for the rest of the living community; simultaneously, it also differentiates us from all other organisms (Potter, 1971b).

By recognizing the unique position above described, enlightened anthropocentrism allows us to abandon the human role as the ruler of nature, and change 
it for the human role as a responsible member of the delicate community of life, aware that its survival depends on this stewardship, and ready to act as an administrator. As expressed by Sagols: "he/she must look after the survival of the forms of life and of the health of the Earth and, at the same time, must satisfy his/her own needs" (Sagols, 2015: p. 25).

Enlightened anthropocentrism could be considered as an analogical alternative towards univocal anthropocentrism and equivocal biocentrism. It enables a defense of the existence of a moral responsibility toward the whole community of life, which would not be sustainable from a perspective of pure anthropocentrism, nor from one of pure biocentrism. The first one, considering humankind as the ruler of nature, could allow a blind and irresponsible exploitation of nature, as we have experienced since the first industrial revolution. The second one, denying humans any special place among other living creatures, could end up considering the extinction of the species as a morally neutral natural process of biological evolution, with no place for responsibility. The analogical alternative seems, therefore, the best option from an ethical point of view.

\subsection{Balancing Essentialism and Existentialism in the Notion of Human Nature}

As discussed in Section 2, an analogical notion of human nature needs to find a balance between the ontological categories of essence and existence. An ethical theory based on a pure essentialist conception of human nature would tend to be univocal, i.e., excessively rigid and formal. An ethical theory based on a pure existentialist conception of human nature would tend to be equivocal, i.e., excessively permissive and relativistic. In consequence, the virtuous interpretation of human nature would take both categories into consideration building "a hybrid, analogical ontology: essential and historical at the same time, because essence is embodied in history." (Beuchot, 2004b: p. 89).

This balance is especially important to bioethics as an interdisciplinary science that should become a bridge between social and biological sciences. An essentialist consideration of human nature, based in biological reductionism, is the first danger. However, the biological essence of human nature, as a constant that connects the enormous diversity of its cultural and historical dimensions, should not be ignored.

There are, indeed, some basic biological requirements to support human life. We need pure water and pure air, we need food and sleep; we need social interaction with others, and a place to protect us from the changing weather. But a deeper analysis reveals that the availability of basic goods such as clean air, food or climate, depend on the ecological interactions of countless biological species.

Going further, like Gómez-Heras does, the analysis could reveal some even more basic features which are valuable to support life in general, and not only human life. From a biocentric point of view, these aspects could be then considered as intrinsic natural values, which should, in consequence, be protected over any other interest-be it individual, communitarian, or even of a singular 
biological species (Gómez-Heras, 2012).

However, some essential components of human nature could also be discovered by means of a historical analysis, without any explicit reference to biology or evolution. This was the method used by the American philosopher Martha Nussbaum to create a list of "basic features of the human figure" (Nussbaum, 1998: p. 63). ${ }^{2}$ Nussbaum uses these basic features to interpret a list of basic human capacities, which would have an intrinsic and universal value. ${ }^{3}$ Therefore, they could provide a common basis for ethical reasoning.

Nussbaum's proposal is an excellent example to illustrate how axiological and normative statements can be derived from some essential features of human nature. It also shows how the ontological categories of essence and existence could be brought into a dialogue to obtain an analogical interpretation.

The description of human capacities is presented in a vague and general way, so that they need to be complemented with contextual information. In doing so, Nussbaum opens a space for analogical interpretation to take place: in different societies, at different historical moments, human capacities can be developed by different means. Nevertheless, the degree to which these basic capacities are developed for every individual can be taken as a parameter morally to evaluate the social relationships of different socio-historical contexts.

It is the vagueness and generality of Nussbaum's definitions that opens the door to the ontological category of existence. This kind of definition should then provide an orientation to the bioethical attempts to balance essentialist and existentialist approaches to human nature. Even if obtained out of biological statements as Gómez-Heras suggests, the essential components of human nature should be expressed in a vague and general form, in order to allow a constant (historical, cultural, contextual, etc.) reinterpretation.

The bioethical imperative of Fritz Jahr is an example of the suggested vague and general formulation. When he calls us to regard every living being as an end in itself and treat it accordingly as far as possible, he allows history and context to define, for every situation, what "as far as possible" means. Even if biological facts should be used to define the scope of this "as far as possible," we should note that biology is a living science; thus, biological facts are susceptible to historical change.

The above leads us to a last consideration: there cannot be, for bioethics, a final, definitive definition of human nature. This notion must be subject to constant reinterpretation because the social and biological sciences that bioethics

\footnotetext{
${ }^{2}$ These basic features would be the following: 1) Mortality; 2) Human body; 3) Pleasure and pain capacity; 4) Cognitive ability; 5) Early childhood development; 6) Sociability; 7) Relation with other species and Nature; 8) Humor and playful sense; 9) Separateness (Nussbaum, 1998: pp. 63-68).

${ }^{3}$ These basic capacities would be the following: 1) To be able to live until the end of a complete human life; 2) Be able to have health; 3) Being able to avoid pain; 4) To be able to use the five senses, imagine, think and reason; 5) Being able to link to people and things outside of ourselves; 6) To be able to form a conception of the good; 7) To be able to live with and for others; 8) To be able to live worried about animals, plants and nature; 9) Being able to laugh, play and enjoy recreational activities; and 10) To be able to live one's own life (Nussbaum, 1998: p. 71).
} 
brings together are also living and changing. The biological facts that Potter claims to be united to ethical values are changing facts, as well as historical, sociological, or political ones. Because the bioethical interpretation of human nature is based on these facts, it is compelled to execute an incessant reinterpretation, which could be guided by analogical hermeneutics.

\section{Conclusion}

The object of this paper was to show how analogical hermeneutics could be applied to bioethics, and to indicate some conceptual contributions that result from that exercise. Although the debate about whether bioethics is a form of applied ethics or a new type of interdisciplinary science (like Potter defended) remains open, its philosophical dimensions require attention. These dimensions include an ethical theory, which can be considered as a form of analogical ethics (Beuchot, 2004a; Beuchot, 2004b; Beuchot, 2004c).

The main aspect that can lead us to consider the ethical component of bioethics as a form of analogical ethics is the fact that bioethics, from its beginnings, seeks to obtain normative statements based on scientific facts, taken mainly (but not only) from the field of the biological sciences. Potter and Jahr, for example, recognized the biological dimension of humanity as an animal species, related to the rest of the other species and immersed in the evolutionary process. The call to treat other living beings as ends in themselves "as far as possible" can also be linked to Jahr's awareness of the existence of some biological self-preservation instincts that are natural to humans. The same instincts appear again in Potter, when he calls bioethics a science of survival that should help our species to prevent its own extinction. Potter's global bioethics is, thus, built upon an evolutionist-based acceptance of the fragility of human nature.

As shown in the previous examples, bioethics constantly uses scientific facts to reinterpret the ontological notion of human nature. That notion becomes a basis to conceive moral values and norms. Thus, an analogical hermeneutical interpretation of human nature is pertinent in order for the obtained moral statements to be realistic and adequate to human possibilities and human needs, as well as not to incur in (fallacious) oversimplifications of the form " $\mathrm{X}$ is natural; therefore, $\mathrm{X}$ is morally acceptable" or " $\mathrm{Y}$ is unnatural; therefore, $\mathrm{Y}$ is undesirable." For example, we know that human life requires the environmental services provided by ecosystems in order to maintain itself. If we also assume that human life (and life in general) is valuable, then we can sustain a moral obligation to protect the integrity of the ecosystems that provides such environmental services. The way this obligation is formulated does not specify how the valuable goal should be achieved. In doing so, it allows a diversity of interpretations in different historical, social and cultural contexts, just as Nussbaum's "basic features of the human figure" did. Analogical hermeneutics promotes this diversity of interpretations, while providing a limit or a basis to it (in this case, the acceptance that life in general depends on the ecosystem services that are, therefore, valuable).

There are even more examples to show how bioethics can profit from the 
orientation that analogical hermeneutics provides to its main philosophical task. For instance, analogical hermeneutics could help to find a mediating position between (univocal) anthropocentrism and (equivocal) biocentrism, which Potter was searching for in his proposal of an "enlightened anthropocentrism" (Potter, 1996). A radical anthropocentrism, like the one we inherited from European modernity, maintains the image of humans as rulers of nature, thus justifying all kinds of violence and exploitation towards other living beings. On the other hand, a radical biocentrism, which does not recognize any "special" value to human life, could trivialize any attempt to avoid the extinction of our species (or even encourage it, in the name of other species' life). Between the two ends, the analogical position of a human being that conceives itself not as a ruler, but as a responsible administrator of nature, like Sagols defends, appears to be the best alternative.

Within the field of medial bioethics, analogical hermeneutics could be applied to solve some problems of the theory developed by Childress and Beauchamp. It could become an alternative to balance principle-oriented and casuistry-oriented decision making, when it comes to actual bioethical dilemmas in medical practice. This kind of approach could also be helpful to approximate the biocentric dimension of bioethics to medial bioethics, which nowadays seems to be much closer to the anthropocentric end. Finally hermeneutical virtue, as Beuchot calls it, could also help bioethicists to find a proportion between essentialist and existentialist approaches to human nature, as well as to balance the contributions of social and biological sciences to the field of bioethics.

The exposition presented in this paper had the modest intention to point out the possibility and pertinence of applying analogical hermeneutics to bioethics, and approaching bioethics through analogical hermeneutics. However, it could also be the starting point for future research. One could envision, for example, a methodology based on analogical hermeneutics to face (practical) bioethical dilemmas. Due to the role that analogy plays within Aristotelian ethics, one could even search for some bioethical virtues that professional bioethicist should develop. A bioethical approach based on virtues could then be linked to other interesting aspects of the discipline's praxis, such as bioethics education, or even the operation of bioethics committees. Since bioethics is ultimately related to bio-politics and bio-law, one could even envision an ethical-political theory with an analogical basis that balanced anthropocentrism and biocentrism, protecting Nature's Rights while ensuring Human Rights.

As a general conclusion of this paper we can sustain that an analogical hermeneutic approach to bioethics not only serve to explain the ethical dimension of bioethical work, but also provides interesting and valuable possibilities for future development of bioethics that would be worth exploring.

\section{Acknowledgements}

The author thanks Dr. Luis Sales Smith for his valuable help with the prepara- 
tion of the manuscript.

\section{References}

Acosta, A. (2011). Los Derechos de la Naturaleza. Una lectura sobre el derecho a la existencia. In Acosta \& Martínez (Eds.), La naturaleza con derechos. De la filosofía a la política (pp. 317-367). Quito: Ediciones Abya-Yala.

Beauchamp, T. L., \& Childress, J. F. (1979). Principles of Biomedical Ethics. Oxford: Oxford University Press.

Beuchot, M. (2003). Hermenéutica analógica y crisis de la modernidad. http://biblioteca.org.ar/libros/1229.pdf

Beuchot, M. (2004a). Ch. 5: Hacia una ética hermenéutico-analógica (pp. 71-87). In Ética. México: Editorial Torres Asociados.

Beuchot, M. (2004b). Ch. 6: La construcción ética (pp. 89-106). In Ética. México: Editorial Torres Asociados.

Beuchot, M. (2004c). Ch. 7: El edificio ético (pp. 107-120). In Ética. México: Editorial Torres Asociados.

Beuchot, M. (2006). Exposición sucinta de una hermenéutica analógica. Communio, 39/2, 237-249.

Beuchot, M. (2008a). Ch. 7: La hermenéutica analógica y la posmodernidad. In Perfiles esenciales de la hermenéutica (pp. 97-110). Mexico: Fondo de Cultura Económica, Universidad Nacional Autónoma de México.

Beuchot, M. (2008b). Ch. 9: Hermenéutica y ética. In Perfiles esenciales de la hermenéutica (pp. 120-129). Mexico: Fondo de Cultura Económica, Universidad Nacional Autónoma de México.

Beuchot, M. (2008c). Ch. 10: La hermenéutica como mediadora entre la metafísica y la ética. La proyección hacia la política. In Perfiles esenciales de la hermenéutica (pp. 130-138). Mexico: Fondo de Cultura Económica, Universidad Nacional Autónoma de México.

Beuchot, M. (2013). Ch. 7: Ética analógica. In Hermenéutica analógica. Lenguaje y sociedad (pp. 99-112). San Luis Potosí: Editorial Universitaria Potosina.

Beuchot, M. (2015). Ch. 1: Elementos esenciales de la hermenéutica analógica. In La hermenéutica y el ser humano (pp. 13-38). Mexico: Ediciones Culturales Paidós.

Callahan, D. (2015). Bioethics: Its Past and Future. In G. Solinis (Ed.), Global Bioethics: What for? (pp. 19-22). Paris: United Nations Educational, Scientific and Cultural Organization.

Carson, R. (1962) Silent Spring, Boston: Houghton Mifflin.

Conde Gaxiola, N. (2001). Ch. 1: Origen y contexto filosófico de la hermenéutica analógica. In Hermenéutica Analógica. Definición y Aplicaciones (pp. 9-16). Mexico: Primero Editores.

Gómez-Heras, J. M. G. (2012). Ch. 6: Valor y deber: De los valores intrínsecos de la naturaleza a los deberes morales. In Bioética y ecología. Los valores de la naturaleza como norma moral (pp. 175-196). Madrid: Editorial Síntesis S. A.

Jahr, F. (1927). Bio-Ethik: Eine Umschau über die ethischen Beziehungen des Menschen $\mathrm{zu}$ Tier und Pflanze. Kosmos. Handweise für Naturfreunde, 24, 2-4.

Nussbaum, M. (1998). Capacidades humanas y justicia social. En defense del esencialismo aristotélico. In Riechmann (Ed.), Necesitar, desear, vivir. Sobre necesidades, desarrollo humano, crecimiento económico y sustentabilidad (pp. 43-104). Madrid: Libros de la catarata. 
Potter, V. R. (1971a). Preface. In Bioethics Bridge to the Future (pp. 7-10). Englewood Cliffs, NJ: Prentice-Hall, Inc.

Potter, V. R. (1971b). Ch. 1: Bioethics, The Science of Survival. In Bioethics Bridge to the Future (pp. 1-29). Englewood Cliffs, NJ: Prentice-Hall, Inc.

Potter, V. R. (1977). Introduction: Evolving Ethical Concepts. BioScience, 27, 251-253. https://doi.org/10.1093/bioscience/27.4.251

Potter, V. R. (1996). Real Bioethics: Biocentric or Anthropocentric? Ethics and the Environment, 1, 177-183.

Rawlinson, M. C. (2015). Bioethics: A Bridge to the Future? In Solinis (Ed.), Global Bioethics: What for? (pp. 31-34). Paris: United Nations Educational, Scientific and Cultural Organization.

Sagols, L. (2013). Ch. 2: Hacia la revolución de la ecoética. In Antiantropocentrismo y la necesidad del antropocentrismo en la ética (pp. 53-77). Mexico: Editorial Fontamara.

Sagols, L. (2015). The Bio-Philia Future of Bioethics. In Solinis (Ed.), Global Bioethics: What for? (pp. 23-26). Paris: United Nations Educational, Scientific and Cultural Organization.

Sass, H. M. (2011). El pensamiento bioético de Fritz Jahr 1927-1934. Aesthetika. Revista internacional sobre Subjetividad, Política y Arte, 6, 20-33.

Steger, F. (2015). Fritz Jahr's (1895-1953) European Concept of Bioethics and Its Application Potential. Jahr, 6, 215-222.

Ten Have, H. A. M. J. (2012). Potter's Notion of Bioethics. Kennedy Institute of Ethics Journal, 22, 59-82. https://doi.org/10.1353/ken.2012.0003 